Financial Market Participation and the Apparent Instability of Money Demand

Samuel Reynard

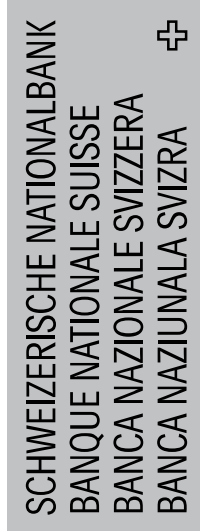

U

(a)

$\frac{2}{2}$

ro

Q

$\frac{0}{5}$

שי 
The views expressed in this paper are those of the author(s) and do not necessarily represent those of the Swiss National Bank. Working Papers describe research in progress. Their aim is to elicit comments and to further debate.

ISSN $1660-7716$

๑ 2004 by Swiss National Bank, Börsenstrasse 15, P.0. Box, CH-8022 Zurich 


\title{
Financial Market Participation and the Apparent Instability of Money Demand
}

\author{
Samuel Reynard*
}

Swiss National Bank

\begin{abstract}
This paper uses multi-period cross-sectional data on financial assets holdings to shed light on the postwar stability of money demand in the United States. I first present a new measure of the evolution of financial market participation, by relating participation to the extensive margins of money demand, and quantify the influence of wealth on participation decisions. I then relate the increase in participation to the period of "missing money" and to the subsequent higher interest rate elasticity of monetary aggregates. The paper indicates that time series estimations of money demand relationships are inherently flawed and tend to inappropriately suggest instability.
\end{abstract}

JEL classification: E41; E44; G11

Keywords: Money Demand; Financial Market Participation; Cross-Sections

\footnotetext{
${ }^{*}$ Swiss National Bank, Research, P.O. Box, 8022 Zurich, Switzerland. Phone: +41 16313216. Fax: +41 1631 3901. Email: samuel.reynard@snb.ch. The views expressed in this paper do not necessarily reflect those of the Swiss National Bank. This paper is based on my Ph.D. thesis at the University of Chicago and is forthcoming in the Journal of Monetary Economics. I am particularly thankful to Robert Lucas and Casey Mulligan, as well as Fernando Alvarez, John Cochrane, Peter Kugler, Annette Vissing-Jørgensen, and an anonymous referee, for helpful discussions and comments. Data were kindly provided to me by Ruth Judson, Casey Mulligan, Richard Porter, and Robert Rasche. The Data Library at the University of Chicago made available to me data from the InterUniversity Consortium for Political and Social Research. Financial support from the Swiss National Science Foundation is gratefully acknowledged.
} 


\section{INTRODUCTION}

Time series studies on money demand often conclude that money holdings are not stable functions of interest rates and scale variables across time and countries, contrary to what economic theory suggests. This paper indicates that time series estimations of money demand are inherently flawed and tend to inappropriately suggest instability. I use cross-sectional evidence to shed light on the stability of postwar money demand in the United States, by relating the evolution of financial market participation to the two most prominent manifestations of time series instability, which are the downward shift in money demand of the 1970s and the subsequent higher interest rate elasticity of monetary aggregates.

The importance of financial market participation cost heterogeneity has recently received attention in the study of money demand. Mulligan and Sala-i-Martin (2000), using the 1989 Survey of Consumer Finances, and Attanasio, Guiso and Jappelli (2002), using surveys on Italian households during the 1990s, have computed welfare costs of inflation by considering explicitly the extensive margins of money demand, i.e., households' decisions on whether or not to enter the financial market and hold part of their wealth in the form of non-monetary interest-bearing assets. In this paper, I use survey data over an extended time period, which allows me to exploit multiperiod cross-sections in order to present a new measure of the evolution of financial market participation and to link participation with the issue of the postwar stability of money demand.

First, the evolution of financial market participation since the early 1960s is presented and analyzed. The notion of participation considered in this paper differs from 
other studies ${ }^{1}$ of financial market participation. I consider specifically financial assets that are substitutable for money, in the sense that by paying some transaction cost, the assets considered, i.e., certificates of deposits, mutual funds, stocks and bonds, can be readily converted into transaction balances. Moreover, the surveys used here cover the past forty years. Both of these features will allow me to identify and assess the effects of large changes in extensive margins and to link participation with the postwar behavior of monetary aggregates.

The different cross-sections allow me to analyze the evolution and determinants of financial market participation and confirm the importance of wealth in participation decisions $^{2}$. I report a 75 percent increase in non-monetary assets participation during the 1960s and 1970s, and confirm the finding of Mulligan and Sala-i-Martin that the probability that a household holds non-monetary assets is positively related to the level of its financial wealth. Indeed, the increase in real financial wealth during the 1960s and 1970s accounts for about a third of the increase in participation during that period. Moreover, the cross-sectional wealth elasticity of participation does not change significantly across periods, thus the effects of secular changes and crosssectional variations in real wealth on participation are the same.

The results are then used to address the apparent instability of monetary time series, by quantifying the influence of changes in financial market participation on

\footnotetext{
${ }^{1}$ For studies of stocks participation, see, for example, Mankiw and Zeldes (1991), and VissingJørgensen (2002). Several publications (Economic Behavior Program Staff; Mandell et al., 1973; SCF reports in Federal Reserve Bulletins) reporting results of Surveys of Consumer Finances, present the evolution of various assets, but their groupings of assets differ from this study and they often include nonmarketable assets which are not taken into account here. The closest concept of participation was proposed by Mulligan and Sala-i-Martin, although my definition considers some assets they include in "interest-bearing assets" as "monetary assets".

${ }^{2}$ For studies of participation determinants, as well as portfolio diversification, see, for example, Blume and Friend (1975), Mulligan and Sala-i-Martin (2000), and Uhler and Cragg (1971), who use single cross-sections or cross-sections covering a few consecutive years.
} 
aggregate money demand. I relate the increase in participation to the period of "missing money" and to the subsequent higher interest rate elasticity of monetary aggregates. The main idea is that as real financial wealth and the opportunity cost of money increased in the 1970s, more people found it worth it to pay the cost of participating in financial markets and hold part of their financial assets in the form of interest-bearing non-monetary assets, instead of holding their entire wealth in the form of monetary assets. This induced a downward shift in money demand as well as a higher interest rate elasticity, as only financial market participants are able to substitute between monetary and non-monetary financial assets when interest rates fluctuate. Thus, increases in financial market participation tend to inappropriately suggest progress in the transaction technology or scale economies in money holdings, and time series estimates of interest rate elasticity are flawed.

The second section presents the evolution of participation in non-monetary financial assets. Section 3 analyzes the determinants of the increase in participation, and section 4 relates the evolution of participation to the issue of money demand stability. The last section concludes.

\section{EVOLUTION OF FINANCIAL MARKET PARTICIPATION}

\subsection{Data Sources}

This section presents how financial market participation has evolved during the postwar period in the United States. For reasons mentioned in the introduction, I consider specifically financial assets that are substitutable for money, in the sense that by paying some transaction cost the assets considered can be readily converted into transaction balances. Thus, for example, I do not include pension funds, IRAs 
or houses, but I include certificates of deposits.

Data on households' financial assets used in this paper are from the Surveys of Consumer Finances $(\mathrm{SCF})^{3}$. SCF have been conducted since 1947, as described in the appendix. The reliability and completeness of the surveys vary substantially between different periods. The best surveys are for the years 1962, 1983, and from $1989 \mathrm{on}^{4}$. These surveys have two parts. The first part consists of a randomly selected, nationally representative, multi-stage area probability sample of all U.S. households. The second part is an additional sample of high-income households, from Federal tax information. This second part is particularly important when measuring participation in the different kinds of financial assets, as the latter are distributed mostly among the most wealthy households. The 1962 survey, called Survey of Financial Consumer Characteristics, is the only pre-1980 survey that is directly comparable to the full samples from the post-1980 surveys, as it also includes an additional sample of highincome households and provides the most comprehensive and detailed inventory of consumers' financial assets of the pre-1980s surveys.

\subsection{Monetary and Non-Monetary Assets: Definitions}

The distinction between monetary and non-monetary assets is not always clear-cut, thus different alternatives will be considered. The main idea is that there are participation costs associated with non-monetary assets (NMA). These costs might include

\footnotetext{
${ }^{3}$ Most information in this sub-section is developed in the codebooks of the different surveys and on the various reports published in different issues of Federal Reserve Bulletin. Both of these sources are available on the Federal Reserve Board internet site. See Avery et al., Economic Behavior Program Staff, Kennickell et al., and Projector et al.

${ }^{4}$ The 1986 survey was designed to update some information in the 1983 survey. Assets were grouped in more aggregated categories, in a way that is not useful for my study of participation. For an analysis of earlier surveys, see publications by the Economic Behavior Program Staff, Mandell et al. (1973), as well as survey reports from Federal Reserve Bulletins in the 1940s and 1950s.
} 
time learning about financial assets and following their development, bankers' time dealing with these assets, time filling out additional tax forms, as well as resources spent evaluating one's financial situation to determine the optimal mix of assets and maturities. However, NMA yield an interest rate at least equal to the 3-month Treasury bill rate. They are also marketable and readily substitutable for money, although at some transaction cost. Thus, for example, houses or pension funds are not considered as NMA for the purpose of this paper.

On the other hand, monetary assets (MA) have a negligible participation cost, as they are standard accounts offered "over the counter" by banks, but have a lower yield than short-term safe market rates, thus they provide transaction or monetary services $^{5}$. The definition of MA corresponds to the concept of monetary services presented in Rotemberg, Driscoll, and Poterba (1995), and to what the report by Kennickell, Starr-McCluer, and Surette (2000) on the 1998 SCF groups as "Transaction Accounts".

Interest rates paid on savings accounts are very similar to the ones paid on unregulated checking accounts, thus savings accounts provide similar transaction or monetary services. They are not checkable but are available on demand. Money market deposit accounts (MMA) were introduced at the end of 1982, as a result of financial deregulation, and yield monetary services as well: they are checkable and were heavily advertised by banks as substitutes for checking and savings deposits ${ }^{6}$. Their participation cost is thus negligible, and their interest rate moves along with the ones on checking and savings deposits, slightly higher but still below the 3 -month Treasury

\footnotetext{
${ }^{5}$ Surveys do not report cash holdings.

${ }^{6}$ See Moore, Porter and Small (1990). For a short period after the introduction of MMA, banks offered higher interest rates on these accounts to attract funds.
} 
bill rate. Moreover, sweep programs ${ }^{7}$ since the mid-1990s have allowed commercial banks to temporarily transfer funds between MMA and other checkable accounts in an optimal timing to reduce the amount of required reserves. Results where MMA are considered as non-monetary assets will also be presented. Money market mutual funds (MMF) present some characteristics of monetary assets as well, as they offer checking features. Only retail funds will be taken into account, as it is the part of MMF that are offered to households and thus can be considered as transaction balances. However, these funds also share some characteristics of non-monetary assets, as their rate evolves closely to market rates and households that decide to hold them have usually spent some resources learning about financial markets. I will thus present results with MMF considered alternatively as monetary and non-monetary assets, and the main results of the paper will not be significantly affected by that choice.

\subsection{Participation in Non-Monetary Financial Assets}

Table 1 presents the evolution of non-monetary assets participation for selected years where the most detailed surveys are available. CD are certificates of deposits, $\mathrm{S}$ are stocks, B are bonds, MF are stock and bond mutual funds, MMF are money market mutual funds, and MMA are money market deposit accounts. Columns (1), (2) and (3) represent participation in at least one of the non-monetary assets on their left-hand side and therefore correspond to alternative definitions of non-monetary assets. Thus, for example, 39.5 percent of U.S. households had either CD, S, B, MF, MMF, or a combination of these assets in their portfolio in 1998. Financial assets

\footnotetext{
${ }^{7}$ See Anderson (1997a, b).
} 


\begin{tabular}{rrrrrrrrrr}
\hline Year & CD & S & B & MF & $(1)$ & MMF & $(2)$ & MMA & $(3)$ \\
\hline $\mathbf{1 9 6 2}$ & - & 17.2 & 2.7 & 4.9 & 20.1 & - & 20.1 & - & 20.1 \\
1968 & 4.4 & 19.2 & & 5.8 & & - & & - & \\
1969 & 4.9 & 20.1 & & 6.4 & & - & & - & \\
1970 & 7.7 & 19.1 & 1.8 & 8.4 & 26.8 & - & 26.8 & - & 26.8 \\
1971 & 13.0 & 17.6 & 3.8 & 8.7 & 28.8 & - & 28.8 & - & 28.8 \\
1977 & 13.6 & 21.8 & 4.4 & 6.5 & 32.3 & - & 32.3 & - & 32.3 \\
$\mathbf{1 9 8 3}$ & 20.1 & 19.1 & 4.2 & 4.5 & 34.0 & 7.2 & 35.6 & 8.9 & 38.5 \\
$\mathbf{1 9 8 9}$ & 19.9 & 16.9 & 5.8 & 7.3 & 33.8 & 5.9 & 34.5 & 16.8 & 41.7 \\
$\mathbf{1 9 9 2}$ & 16.7 & 17.0 & 4.3 & 10.4 & 33.4 & 6.0 & 34.6 & 16.9 & 40.4 \\
$\mathbf{1 9 9 5}$ & 14.3 & 15.2 & 3.1 & 12.3 & 32.4 & 5.7 & 33.5 & 14.1 & 38.9 \\
$\mathbf{1 9 9 8}$ & 15.3 & 19.2 & 3.0 & 16.5 & 38.2 & 6.3 & 39.5 & 13.3 & 44.0 \\
\hline
\end{tabular}

The most reliable survey years are in bold. CD: certificates of deposits;

S: stocks; B: bonds; MF: stock and bond mutual funds;

MMF: money market mutual funds; MMA: money market deposit accounts.

Columns (1), (2) and (3) represent participation in assets on their left-hand side.

Table 1. Non-Monetary Assets Participation (Percent of U.S. Households)

held through pension accounts, trusts, thrift-savings, 401-K or IRA/Keogh plans are not included, as I focus on assets relevant for money demand margins.

Certificates of deposits are time deposits. Their yield is above the 3-month Treasury bill rate but they have a fixed maturity and early withdrawal is subject to a substantial penalty. Households started to hold significant amounts of CD in the late 1960s and the percentage of holders increased during the 1970s. Before 1977, all CD were issued with fixed interest rates $^{8}$, but in $1977 \mathrm{CD}$ with flexible interest rates tied to the Treasury bill rate were introduced. As interest rates increased sharply during the 1970s, and given that interest rates offered on checking and saving balances were regulated, the fraction of households holding CD increased sharply and accounted for a large part of the overall increase in financial market participation. Then, in the early 1990s, participation in CD declined and was offset by an increase in stock and

\footnotetext{
${ }^{8}$ For an analysis of financial market innovations, see Mishkin (1986).
} 
bond mutual funds participation, as equity prices and long-term interest rates were rising $^{9}$.

The percentage of households with direct holdings of stocks ${ }^{10}$ remained almost constant throughout the period. Direct holdings of bonds ${ }^{11}$ remained constant as well, and the percentage has remained almost negligible. However, indirect holdings of both those assets increased through mutual funds. Holdings of stock and bond mutual funds (MF) increased substantially in the early 1990s and in the late 1990s with the particularly outstanding stock market performances. Figures in column MF from the 1960s and 1970s surveys that are not in bold seem abnormally high and should be interpreted with caution as those surveys are not as precise. Money market mutual funds (MMF) were introduced in the early 1970s and became popular with the interest rate increase in the late 1970s, particularly since 1978. Money market deposit accounts (MMA) were introduced as a result of financial deregulation in late 1982, as discussed above, and some adjustment occurred in between the 1983 and 1989 surveys.

From columns (1), (2) and (3), we see that most of the increase in participation occurred during the 1960s and 1970s, i.e., before financial deregulation, and the increase came mainly from an increased participation in certificates of deposits. As documented by Kennickell et al., the increase in participation in 1998 can be explained by the fact that the share of financial assets in total assets rose, mostly through direct and indirect holdings of stocks, whereas the share of non-financial as-

\footnotetext{
${ }^{9}$ See Collins and Edwards (1994).

${ }^{10}$ Stocks consist of publicly traded stocks, but does not include stocks held through mutual funds, which are accounted in mutual funds (MF).

${ }^{11}$ Bonds do not include bonds held through mutual funds, which are accounted in mutual funds (MF). Separate data on marketable bonds holdings were not available for 1968 and 1969. U.S. government savings bonds are not included, as they are nonmarketable and have restrictions attached to their purchase and selling, which makes their substitutability for money questionable.
} 
sets, like vehicles, real estate, and businesses, fell correspondingly. We will come back to this fact in the next section.

The main finding of this section is thus a substantial increase in non-monetary assets participation in the 1960s and 1970s, and a stabilization of participation thereafter. This evolution will be analyzed in section 3, and used to shed light on the evolution of monetary aggregates in section 4 .

\section{DETERMINANTS OF FINANCIAL MARKET PARTICIPATION}

\subsection{Approach and Empirical Model}

In this section, I present evidence on the influence of changes in real financial wealth on participation, and discuss the contributions of changes in interest rates and participation costs to financial market participation. The main result is that about a third of the increase in participation during the 1960s and 1970s is due to an increase in real financial wealth during that period. Moreover, by isolating the influence of wealth on participation, we are able to determine that the factors accounting for the remaining two-thirds of the participation increase were linked to the particular economic and regulatory environment of the 1970s.

An empirical framework is presented by Mulligan and Sala-i-Martin, who use the 1989 SCF and point out that a large fraction of households do not hold non-monetary assets. They suggest that there is a cost of participating in the financial market and present a model where households choose to participate in the financial market, i.e., adopt non-monetary assets, only if the participation cost is smaller than the benefit of participating, i.e.,

$$
\psi \leq \alpha R A
$$


where $\psi$ is the participation cost, $A$ is the total amount of financial assets, i.e., monetary and non-monetary assets, held by the household, $\alpha$ is the fraction of assets invested in non-monetary assets once the participation cost has been paid, that represents the intensive margins of money demand, and $R$ is the interest rate differential between non-monetary and monetary assets, i.e., the opportunity cost of monetary assets.

I first display some evidence on the importance of real financial wealth on participation decisions and compare participation decisions in 1962 relative to the 1980s and 1990s. Then a non-parametric approach is used to quantify the influence of wealth and other factors on the increase in participation during the 1960s and 1970s, and probit estimates of the influence of wealth on participation decisions are presented. Finally I suggest ways of measuring the effects of changes in interest rates and participation costs.

\subsection{Role of Financial Wealth in Financial Market Participation}

Figure 1 displays the fraction of financial market participants against the amount of real financial wealth (in 1992 dollars) for the years 1962 and 1983. Each point on the graph represents the mean of a wealth centile, together with the (non-weighted) fraction of households holding strictly positive amounts of non-monetary assets in that centile. It is clear from these cross-sections that participation in non-monetary assets is an increasing function of wealth. It is also clear that participation, for a given level of real wealth, was higher in 1983 than it was in 1962. This reflects the influence of variables other than wealth on participation decisions. On the other hand, similar plots for the 1980s and 1990s reveal that participation remained a stable function of 


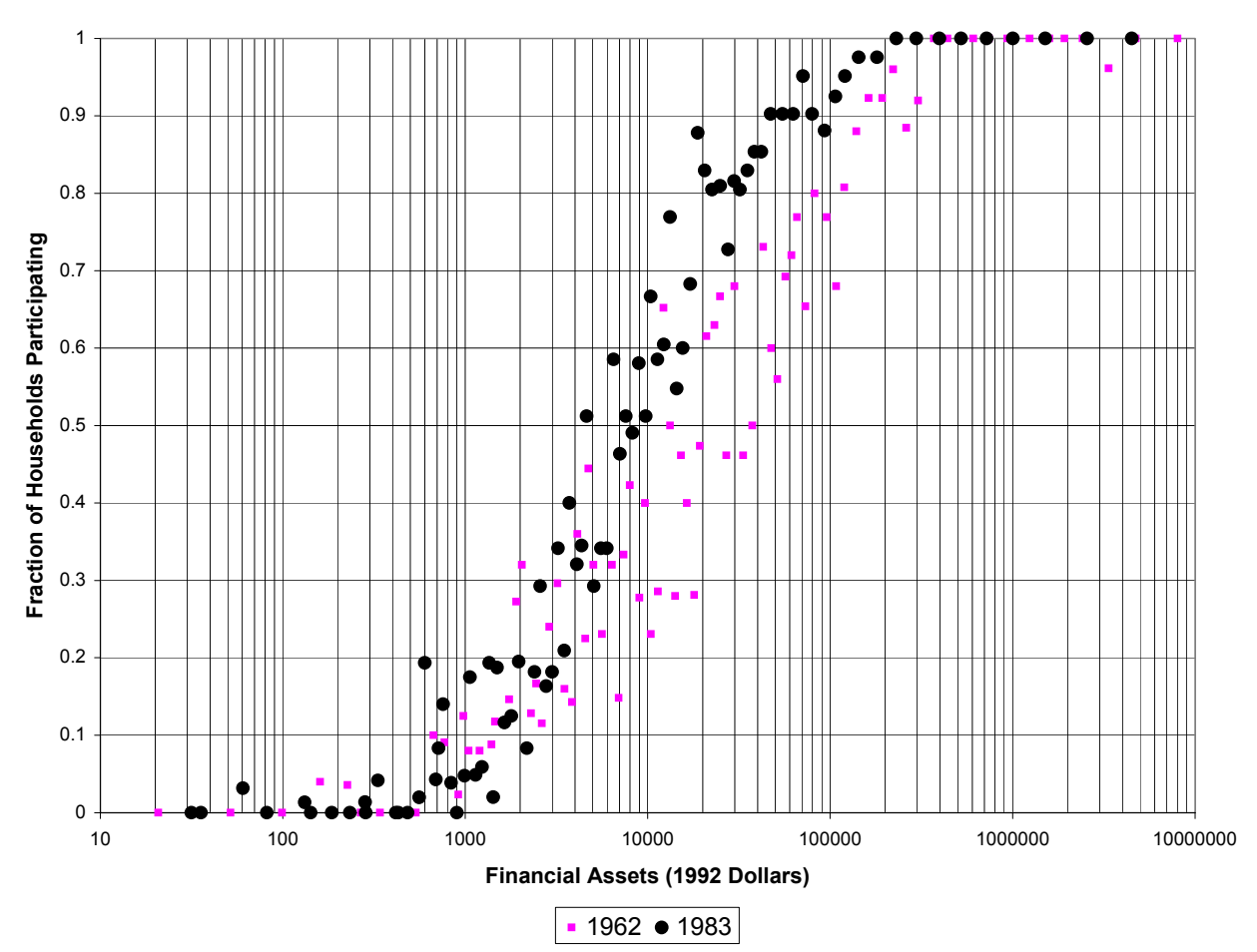

FIG. 1. Wealth and Participation: 1962 vs. 1983

wealth during the last two decades. In terms of wealth evolution, the cumulative real wealth distribution over U.S. households shifted to the right between 1962 and the post-1980 period, with a median real wealth increase of about 20 percent.

The following non-parametric approach allows us to quantify the importance of changes in real financial wealth on financial market participation without relying on functional forms. I divide the distribution of the logarithm of real wealth into intervals of equal size, and for each interval I compute the fraction of households holding strictly positive amounts of non-monetary assets as well as the number of households in that interval. Thus, for every year we have a wealth distribution and participation as a function of wealth. Table 2 displays the percentages of households 
participating, given a participation function and a wealth distribution. The first

\begin{tabular}{lccccc}
\hline Participation/Wealth & 1962 & 1983 & 1992 & 1995 & 1998 \\
\hline 1962 & 20.1 & 24.5 & 24.8 & 23.6 & 28.5 \\
1983 & 29.8 & 34.0 & 34.5 & 32.5 & 38.7 \\
1992 & 30.0 & 34.0 & 33.4 & 32.4 & 38.9 \\
1995 & 29.2 & 34.2 & 34.4 & 32.4 & 38.8 \\
1998 & 29.3 & 33.9 & 33.8 & 32.4 & 38.2 \\
\hline
\end{tabular}

Columns represent wealth distributions in given years.

Rows represent participation as a function of wealth, for given years.

Table 2. Non-Parametric Counterfactual Participation

row gives the percentage of households that would have held non-monetary assets in 1962 if the wealth distribution had been the one of 1983, 1992, 1995 or 1998, with the participation as a function of wealth of 1962 . We can see from that first row that wealth caused participation to increase in between 1962 and 1983, and to remain constant thereafter, except for the 1998 increase. The first column represents the increase in participation due to factors other than wealth, i.e., due to a change in participation as a function of wealth, like persistent changes in interest rates or participation costs. At 1962 wealth, participation would have increased between 1962 and 1983, and remained almost constant thereafter. We can therefore compute the share of the increase in participation attributable to a change in wealth, which turns out to be about one-third ${ }^{12}$. Similar calculations with a semi-parametric approach, using estimated probit curves as the probability of participation as a function of wealth, yield similar results. It is interesting to note that the factors accounting for the remaining two-thirds of the increase in participation during the 1970s do not

\footnotetext{
${ }^{12}$ This fraction varies slightly across years as the opportunity cost of monetary assets fluctuates. In 1998, the share of financial assets in total assets rose, and this change in real financial wealth accounts for all of the increase in participation that year. When compared to 1962, the increase in financial wealth accounts for almost half of the increase in participation in that case.
} 
affect participation at all during the 1980s and 1990s. These factors are thus linked with particular developments that occurred in the 1970s, and their role is assessed in the next section.

Results from probit estimations are displayed in Table 3. The dependant variable

\begin{tabular}{lrrr}
\hline & All Years & Post-1980 & \multicolumn{1}{c}{1962} \\
\hline Wealth & .548 & .554 & .504 \\
& $(.007)$ & $(.007)$ & $(.02)$ \\
Dummy & .271 & & \\
& $(.037)$ & & \\
Constant & -5.373 & -5.155 & -4.947 \\
& $(.075)$ & $(.069)$ & $(.193)$ \\
Obs. \# & 19,664 & 17,473 & 2,191 \\
\hline Standard errors in parenthesis.
\end{tabular}

Table 3. Probit Estimates of the Participation Decision

takes the value 1 if the household holds non-monetary assets, i.e., if the household participates in the financial market, and zero otherwise. "All Years" means that all cross-sections are pooled together, i.e., 1962, 1983, 1989, 1992, 1995 and 1998, with a total of 19,664 observations. The "Post-1980" column excludes the 1962 survey, and the last column considers only the 1962 survey. "Wealth" represents the logarithm of real financial wealth (in 1992 dollars), and the dummy takes the value zero in 1962 and 1 afterwards to account for the increase in participation between 1962 and the 1980s and 1990s not accounted for by wealth, i.e., the factors that account for the increase in participation in the columns of Table 2. The results of these estimations confirm with multi-period cross-sections what Mulligan and Sala-i-Martin found with a single cross-section, i.e., that wealth is an important factor in financial market participation. Adding additional demographic explanatory variables to the equation does not change the coefficient on wealth significantly, and the effects of these additional variables are 
negligible and insignificant.

\subsection{Contribution of Interest Rates and Participation Costs}

Attributing the remaining part of changes in participation to variations in interest rates and participation costs is a difficult task, as participation costs are not observed. Another problem is the measurement of the opportunity cost, as non-monetary assets include stocks and bonds, for example. In the computations of this section, I will use the 6-month commercial paper rate as the benchmark rate for non-monetary assets. This approximation can be legitimate as most of the increase in participation occurred during the 1970s through certificates of deposits, which pay an interest rate close to the 6-month commercial paper rate.

From equation (1), both interest rate and wealth affect participation decisions. The opportunity cost of monetary assets, computed as the difference between the 6-month commercial paper rate and a weighted average of the interest rates paid on monetary assets, was 1.5 percent in 1962, and this value was also the average of the opportunity cost during the postwar period before it started rising in the mid-1960s. In the 1980s and 1990s, checkable and savings deposits have been yielding interest and have not been subject to interest rates ceilings. Their opportunity cost has been trendless but fluctuating, as banks do not pass short-term market rates fluctuations on deposit rates ${ }^{13}$, and it averaged at 2.5 percent during the deregulated period. We can compute the share of the increase in participation attributable to changes in interest rates using the non-parametric method described above, with the product of wealth times the opportunity cost as an explanatory variable for participation. The

\footnotetext{
${ }^{13}$ See Moore, Porter and Small (1990).
} 
increase in opportunity cost turns out to account for about a third of the increase in participation, so that wealth, interest rates and participation costs account each for a third of the increase in participation.

Using the fact that both interest rate and wealth affect participation, we can obtain further knowledge on the nature of participation costs. Assuming a per period cost only, the non-parametric methodology can be used to recover the cost function for given years. In this case however, the resulting implied cost would fluctuate over time in an implausible way, as the behavior of participation in the 1980s and 1990s is too smooth relative to opportunity cost fluctuations. Thus a per period cost does not appear to be the only relevant cost, and part of the cost of participating must take the form of a once-and-for-all entry cost or a fixed cost. As panel data are not available, I estimated a probit model with lagged opportunity costs, and found that changes in interest rates have very persistent effects on participation, but coefficients could not be precisely estimated. Moreover, those findings are consistent with the evidence presented in Vissing-Jørgensen (2002), who analyses participation cost structures using repeated-panel data. She finds evidence for the presence of important fixed and/or entry costs and for the potential role of per period costs, but was not able to quantify the relative importance of those costs even with panel data.

The presence of a cost not to be renewable every year or even a once-and-for-all cost of entering the financial market can explain the evolution in participation presented in this paper. The increase in inflation and interest rates in the 1970s, combined with regulations on deposits' interest rate ceilings ${ }^{14}$, prompted households to learn about financial markets and interest-bearing assets like certificates of deposits or mutual

\footnotetext{
${ }^{14}$ Regulation-Q imposed ceilings on the interest rate paid on savings accounts and checking accounts were not allowed to pay any explicit interest.
} 
funds. This also prompted financial institutions to offer alternative assets and to provide more easily accessible information about these assets, thus decreasing participation costs. After that episode, people did not withdraw much from non-monetary assets when interest rates declined in the 1980s, since they had already acquired knowledge about financial markets. Therefore, long-lasting changes in interest rates have significant effects on participation, and thus on money demand relationships as we will see below.

\section{EXTENSIVE MARGINS AND MONEY DEMAND STABILITY}

This section uses the analysis of financial market participation presented above to address the issue of money demand stability. Two particular events lead economists to question the stability of money demand. The first one was the period of "missing money" in the 1970s, when standard money demand equations systematically overpredicted actual money holdings ${ }^{15}$. Then, following that episode, transaction balances became more sensitive to interest rate fluctuations ${ }^{16}$.

The idea behind using cross-sections to understand time series of monetary aggregates is that both the downward shift in money demand and the subsequent higher interest rate elasticity observed in time series can be understood in the presence of a fixed cost of holding non-monetary financial assets. As real financial wealth and the opportunity cost of money increase, as they did in the 1970s, more people find it worth it to pay the cost and hold part of their financial assets in the form of interest-bearing

\footnotetext{
${ }^{15}$ See Judd and Scadding (1982).

${ }^{16}$ In the 1970s, M1 became a target for monetary policy, as its velocity had been increasing smoothly over the 1960s and 1970s. However, the response of M1 velocity to its declining opportunity cost in the early 1980s was interpreted as a sign of instability, and M1 was downgraded in policy decisions, as reported in Judd and Motley (1984), who argued against the apparent instability.
} 
non-monetary assets. This induces a downward shift in money demand, as well as a higher interest rate elasticity, as only financial market participants can substitute between monetary and non-monetary assets when interest rates fluctuate.

I first present the evolution of monetary assets during the postwar period, and then assess the influence of changes in participation on aggregate money demand, relating the increase in financial market participation to the apparent instability of money demand.

\subsection{Time Series Behavior of Monetary Assets}

Figure 2 displays the velocity of monetary assets (MA) introduced in section 2, together with their opportunity cost and the 3 -month Treasury bill rate ${ }^{17}$. MA consist of currency, demand deposits, other checkable deposits, money market deposit accounts, retail money market mutual funds, and savings accounts ${ }^{18}$. As discussed in section 2, MA have negligible participation costs and provide transaction or monetary services. The influence of the increase in financial market participation on the two apparent sources of instability of monetary assets, namely the upward shift in velocity in the 1970s and the higher interest rate sensitivity in the 1980s and 1990s, is assessed in this section.

The effect of the velocity shift on money demand relationships appears clearly when we plot the real money-income ratio against the opportunity cost of MA, as shown

\footnotetext{
${ }^{17}$ Velocity is nominal GDP divided by MA. The opportunity cost is the 3-month Treasury bill rate minus the weighted average of interest rates paid on the different monetary assets.

${ }^{18}$ Data sources are displayed in the appendix. MA correspond to M2 minus small time deposits. The report on the 1998 SCF groups these assets as "Transaction Accounts" (see Kennickell et al., 2000). For a study of monetary assets in the context of Divisia or Currency-Equivalent indexes, see Rotemberg et al. (1995). Motley (1988), Poole (1991), and Carlson and Keen (1996) consider a group of assets close to this one with an analysis based on maturities.
} 


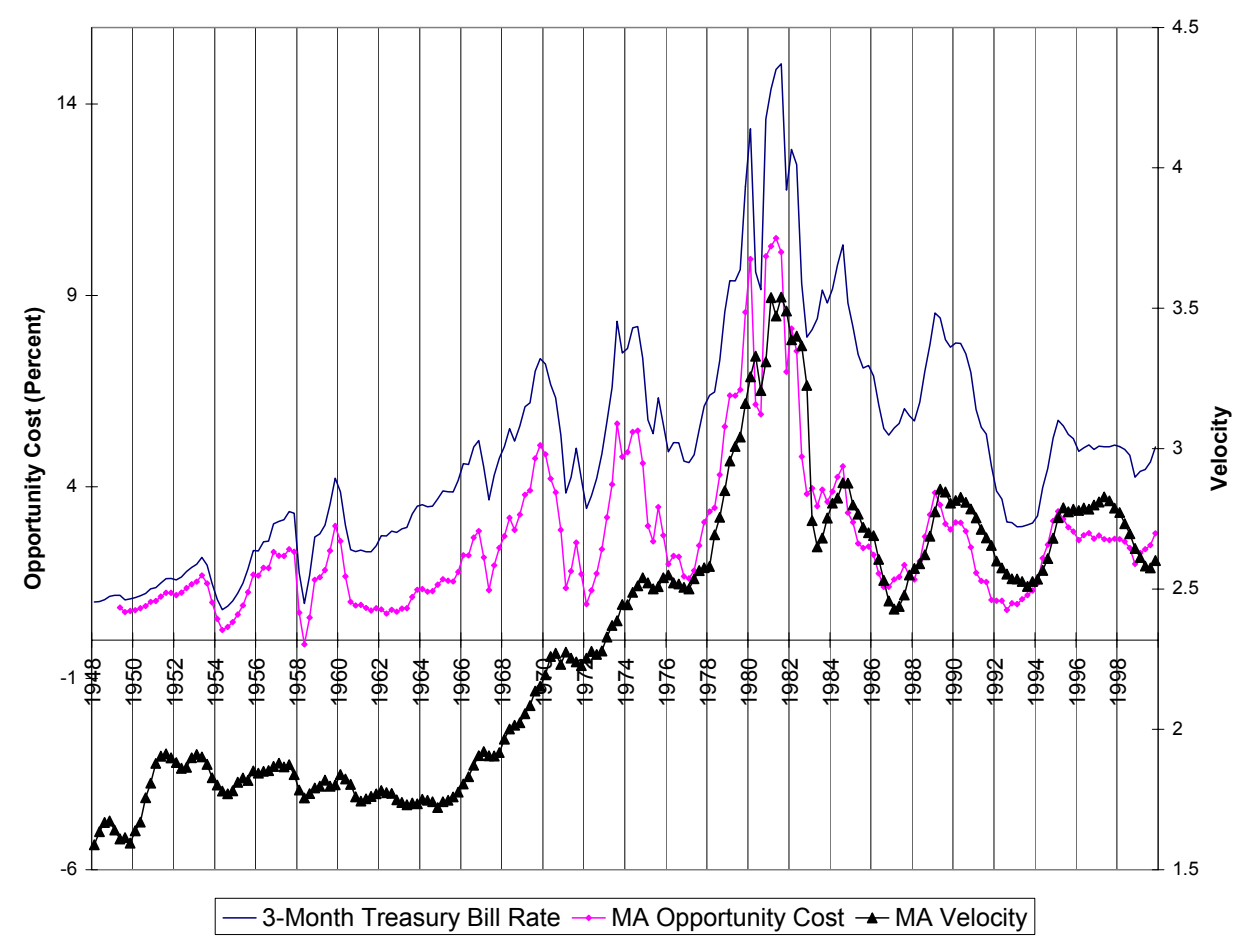

FIG. 2. MA Velocity

in Figure 3. There is a clear relationship between the inverse of velocity and the opportunity cost when both periods, before (1949-1969) and after (1977-1999) the velocity shift, are considered separately. Time series estimations are presented at the end of this section, in Table 4. The interest rate elasticity is higher after the velocity shift than before, and the income elasticity is not significantly different from unity in the two sub-samples.

\subsection{Households' Participation and Aggregate Money Demand}

We can make two interesting observations from Figure 2 and column (1) of Table 1. First, the upward velocity shift at the end of the 1960s and in the 1970s corresponds 


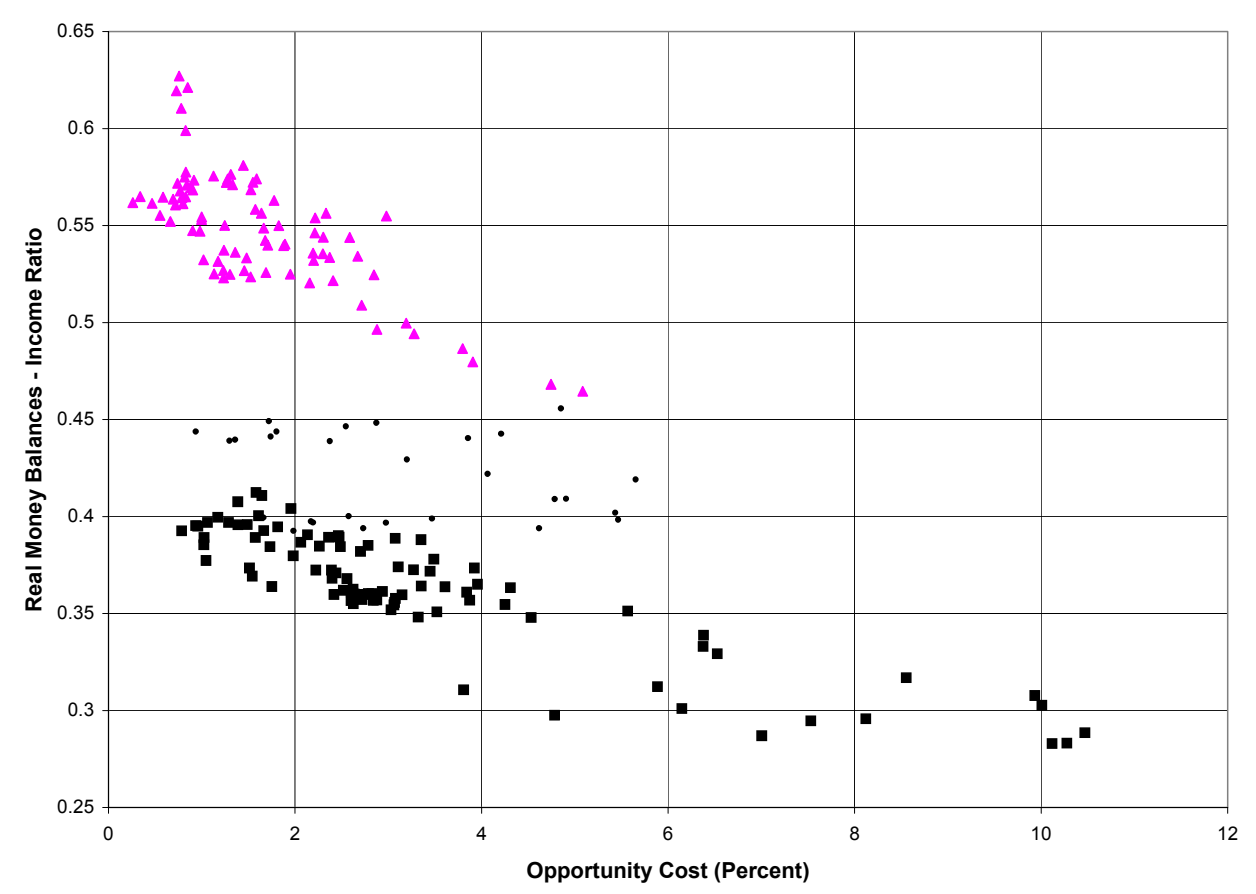

ـ1949-1969 • 1970-1976 - 1977-1999

FIG. 3. Quarterly Money Demand (1949-1999)

to a period where the fraction of households holding non-monetary assets increased significantly; and later, in the 1980s and 1990s, when the fraction of financial market participants remained almost constant, MA velocity followed closely the opportunity cost. The second interesting observation is that, from Figure 2, the interest rate elasticity of money demand seems to be higher in the 1980s and 1990s, when participation was higher, than in the 1950s and 1960s. I will characterize the effects of changes in participation on these two facts.

It is also instructive to compare the evolution of $\mathrm{M} 1$ velocity $^{19}$, presented in Figure 4, with the evolution of financial market participation in Table 1. Before 1980, the velocity of M1 increases without being very sensitive to short-term interest rates

\footnotetext{
${ }^{19} \mathrm{M} 1$ consists of currency, demand deposits and other checkable deposits.
} 


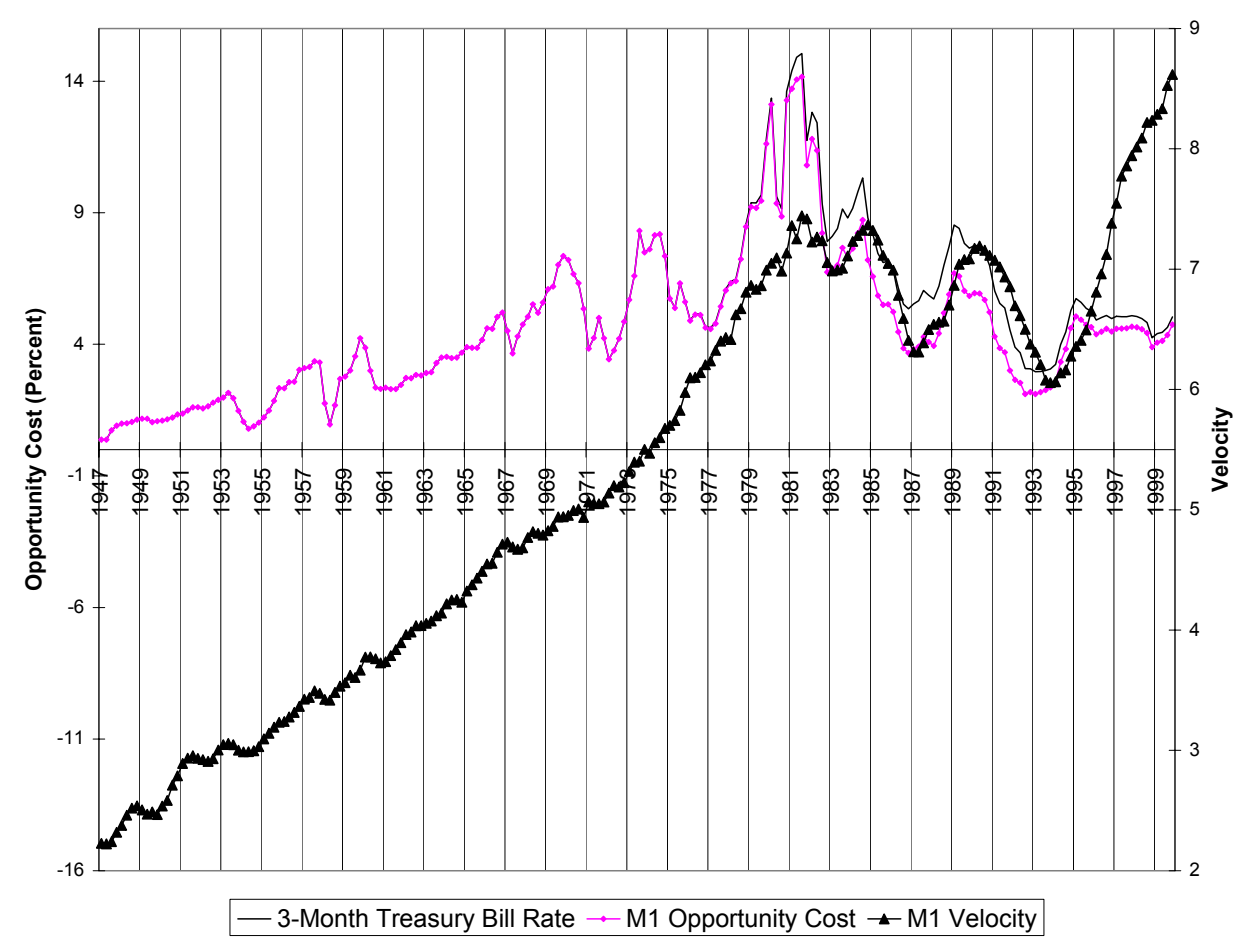

FIG. 4. M1 Velocity

fluctuations. After 1980 however, it follows very closely its opportunity cost, until the late 1990s when sweep programs were introduced, as discussed in section 2.2. The pre-1980 increase can be partly explained by the increase in financial market participation, as I will argue below, together with the usual intensive margins from the increase in interest rates. After 1980, when participation is steady and higher than in the 1960s and 1970s, M1 velocity is more sensitive to interest rate fluctuations than in the past and does not trend upwards anymore.

A common argument ${ }^{20}$ for the "missing money" episode is that the increase in velocity was concentrated on demand deposits and was due to improved cash manage${ }^{20}$ See Porter, Simpson and Mauskopf (1979), Judd and Scadding (1982), and Dotsey (1985). 
ment techniques by firms. However, data on Demand Deposit Ownership Surveys ${ }^{21}$ conducted at the Federal Reserve Board show that, while there has indeed been an increase in the ratio of demand deposits owned by firms relative to households during the 1970s, this explanation is not sufficient to account for the velocity shift. In particular, the ratio does not change much with the two interest rate drops. Moreover, the velocity of savings accounts exhibits an upward shift in velocity as well, and firms were not allowed to hold these accounts before the mid-1970s, and held only a small fraction of the total amount of these accounts thereafter. Accounting for the behavior of households as well is thus needed. Another reason to focus on participation for the upward velocity shift and the higher interest rate elasticity of monetary assets is that, in the late 1960s and 1970s, a sharp and substantial increase in the amount of small time deposits (CD under $\$ 100,000$ ), which accounted for most of the increase in participation, corresponds precisely to the downward shift in the demand for monetary assets, and then the velocities of CD and MA moved in opposite directions, reflecting changes in opportunity costs and substitutions between monetary and non-monetary assets.

While it is not possible to quantify precisely the relative share of households' money holdings, some facts from time series, the nature of different accounts and data from the Flow of Funds Accounts allow us to state that households hold the main part of MA. Savings accounts represented about 60 percent of MA in the 1960s and 1970s, and were offered exclusively to households until the mid-1970s. Even though firms have been allowed to hold them since, Flow of Funds data, and Porter et al. (1979) suggest that the firms' share of these accounts has been small. In the 1980s and 1990s, the share of savings accounts and money market deposit accounts in MA went down

\footnotetext{
${ }^{21}$ See Farr, Porter, and Pruitt (1978).
} 
to about 45 percent, and the share of retail money market mutual funds (MMF) rose to about 15 percent. Flow of Funds data indicate that corporate businesses hold less than 10 percent of the total amount of MMF outstanding in the 1980s and 1990s. Moreover, MMF considered here do not include funds held by institutional investors, called institutional money market funds, thus most of MMF included in MA are held by households. Data on currency and checking accounts (demand deposits and other checkable deposits) provide less useful information, as these assets can be held by firms as well as households, and Flow of Funds data are very different from the Demand Deposit Ownership Surveys conducted at the Federal Reserve Board. However, given that "other checkable deposits" account for about half of the total amount of checking deposits in the 1980s and 1990s, and that they were offered exclusively to households, we can confidently say that households hold a large part of checking accounts as well.

To measure the extend to which the velocity of money held by households has shifted in the 1970s, I compute the upward shift in velocity between two years for which surveys were available and when the opportunity cost of monetary assets was similar, to isolate the upward velocity shift from variations in money demand caused by interest rate changes. Given the evolution of the opportunity cost displayed in Figure 2 and the different surveys presented in Table 1, it is natural to compare 1962 with 1992: financial market participation had stabilized in 1992 and the opportunity cost of monetary assets was at the same level than in 1962. The velocity of monetary assets increases by 25 percent between the two periods. The causes of this upward velocity shift will be assessed in the next section. 


\subsection{Participation and the Velocity Shift}

This section quantifies the influence of the increase in financial market participation on the downward shift in households' money demand. The main finding is that without the increase in financial market participation, the upward shift in velocity would not have occurred.

First note that aggregate money demand can be expressed ${ }^{22}$ as

$$
M=\sum_{(A, T)}\left[\Phi(A, \mu) M^{P}(R, T)+[1-\Phi(A, \mu)] A\right] N_{(A, T)},
$$

where $A$ is financial wealth, $T$ can represent a measure of transactions or wealth, $R$ is the opportunity cost of monetary assets, $\Phi(A, \mu)$ is the fraction of households participating in the financial market, which is a function of wealth and of the average participation cost $\mu$ that can potentially vary across years ${ }^{23}, M^{P}(R, T)$ is money demand of participants, and $N_{(A, T)}$ is the number of households with wealth $A$ and transactions $T$. For given levels of $A$ and $T$, money holdings are the actual number of households with these wealth and transactions levels, times average money holdings. Households which do not participate in the financial market hold all their financial wealth in the form of money, thus their money demand is equal to their actual financial wealth, and households which do participate invest part of their financial wealth in non-monetary assets and keep the amount $M^{P}(R, T)$ as money holdings. To quantify the effect of the increase in participation on the upward velocity shift, I use a nonparametric method similar to the one used in section 3, and obtain for each year

\footnotetext{
${ }^{22}$ This way of expressing aggregate money demand is derived from Mulligan and Sala-i-Martin.

${ }^{23}$ Section 3 provides evidence that persistent changes in interest rates affect participation, thus $\mu$ incorporates this influence as well.
} 
a wealth distribution, financial market participation as a function of wealth, and a money demand function for participants.

The actual velocity of households' money holdings increased by 25 percent between 1962 and 1992. We first examine the effect of a potential exogenous shift in the money demand of participants on velocity. We can use the participants' money demand of 1992 instead of the money demand of 1962, and hold everything else constant, i.e., with the wealth distribution and participation as a function of wealth of 1962 , to find out the part of the upward velocity shift that can be explained exclusively by a potential exogenous shift in the demand for money by participants. As in the previous section, I consider the year 1992 because the opportunity cost of MA in 1992 was similar to the one in 1962, so that a potential shift in money demand could not have been caused by a change in interest rate. We are thus asking the question: "What would have been the velocity in 1962 with the 1992 money demand function?". The velocity computed from such a simulation is almost identical to the actual velocity in 1962. Therefore we conclude that the upward velocity shift was not caused by an exogenous downward shift in the participants' money demand alone.

Considering now the effect of a change in participation, we compute what would have been the velocity in 1962 with the 1992 participation function $\Phi\left(A, \mu_{1992}\right)$ instead of $\Phi\left(A, \mu_{1962}\right)$, holding everything else in 1962 values. This simulation isolates the increase in participation not explained by wealth, which represents two-third of the total participation increase, and thus allows us to find a lower bound for the effect of the increase in participation on the upward velocity shift. With this simulation, velocity increases by 15 percent. Thus the change in participation alone explains more than half of the actual velocity increase between 1962 and 1992. 
When the increase in the participation function is combined with the shift in the money demand function, i.e., when the money demand of 1992 and the participation function $\Phi\left(A, \mu_{1992}\right)$ are used with the wealth distribution of 1962 , the simulated velocity increases by about 20 percent. The reason why the change in money demand by itself has a negligible impact but its combined effect with the increase in participation is significant, is that the increase in participation makes an exogenous shift in money demand more effective, as more people are affected by a shift in the money demand function when a larger portion of the population participates. Thus there has been a small exogenous downward shift in money demand for participants between 1962 and the 1980s and 1990s, but without a change in participation this shift would not have generated an upward shift in aggregate velocity.

\subsection{Participation and Aggregate Elasticity}

To assess the influence of participation on the aggregate interest rate elasticity, consider again aggregate money demand as expressed in equation (2). The aggregate interest rate elasticity can then be expressed as

$$
\frac{d \ln M}{d \ln R}=\epsilon_{R}^{P} \sum_{(A, T)}\left[\Phi(A, \mu) \frac{M^{P}(R, T)}{M}\right] N_{(A, T)},
$$

where $\epsilon_{R}^{P}$ is the interest rate elasticity for participants. The aggregate money demand elasticity is thus equal to the elasticity of money demand for participants times the share of total money demand held by participants.

The actual share of money demand for participants was 49 percent in 1962 and remained almost constant around 72 percent in the 1980s and 1990s. The aggregate 
interest rate elasticity has thus increased by almost 50 percent due to the increase in participation. Estimating money demand with time series alone can thus lead to apparent instability while the elasticity of money demand for participants remains constant over time, as the distribution of financial wealth changes or after a persistent increase in interest rates or a decline in participation costs.

\begin{tabular}{lccc}
\hline & Pre- Velocity Shift & Post- Velocity Shift & Postwar \\
\hline Interest Rate Elasticity $\left(\theta_{r}\right)$ & -.065 & -.134 & -.137 \\
& $(.031)$ & $(.017)$ & $(.059)$ \\
Income Elasticity $\left(\theta_{y}\right)$ & 1.001 & .976 & .711 \\
& $(.074)$ & $(.047)$ & $(.077)$ \\
\hline
\end{tabular}

Standard errors in parenthesis.

Table 4. Time Series Estimates

Time series estimates are presented in Table 4. The cointegrating relation

$$
m_{t}-p_{t}=\theta+\theta_{y} y_{t}+\theta_{r} r_{t}
$$

is estimated by dynamic ordinary least squares (Stock and Watson, 1993) with quarterly data ${ }^{24}$. $m$ is MA, $p$ is the GDP price deflator, $y$ is real GDP, and $r$ is the opportunity cost of MA as defined in section 4.1. All variables are in logarithm.

The interest rate elasticity increases (in absolute value) from -.065 before the velocity shift (1949-1969), to -.134 for the period following the shift (1977-1999), while the income elasticity remains not significantly different from unity. Estimation results for the earlier period are less precise and should be interpreted with caution, as partici-

\footnotetext{
${ }^{24}$ Regressions use one lead and lag of the first differences and an $\operatorname{AR}(2)$ process for the error. Adding additional leads and lags does not affect the results significantly. The income elasticity remains not significantly different from unity in the two sub-samples but significantly lower for the whole sample, and the relative size of the interest rate elasticity between the two periods varies slightly but post- velocity shift estimates remain higher.
} 
pation might have changed during that period ${ }^{25}$. Similar results are obtained when the 6-month commercial paper rate is used as the benchmark risk-free rate instead of the 3-month Treasury bill rate, with the aggregate interest rate elasticity increasing from -.1 to -.15. Moreover and not surprisingly, estimating money demand using time series covering the whole postwar period leads to substantially different results. Coefficients are not precisely estimated and the income elasticity appears significantly lower than unity.

Given that the opportunity cost and velocity show no trend in the two sub-periods, we obtain a unitary income elasticity for those samples. As the increase in participation induced a decline in money holdings while income was growing, the income elasticity estimated over the postwar period is biased downward. Increases in financial market participation thus tend to inappropriately suggest progress in the transaction technology or scale economies in money holdings. Moreover, the fact that interest rates increased when the downward money demand shift occurred produces an upward bias in the estimated postwar interest rate elasticity, which turns out to be higher than an average of the coefficients estimated for the two sub-samples. The estimated interest rate elasticity is further flawed by the fact that the underlying aggregate interest rate elasticity was evolving during the 1970s, as progressively more people became able to substitute between monetary and non-monetary assets.

\section{CONCLUSION}

Money demand studies have mostly been based on time series analysis, and many of them concluded that money demand relationships are not stable across time or

\footnotetext{
${ }^{25}$ A sample starting in 1952, after what appears as a velocity shift, leads to similar results. The second sample starts in 1977 as participation had stabilized then (see column (1) of Table 1).
} 
countries. As a consequence, interest in this line of research has faded and monetary aggregates have been downgraded in monetary policy discussions. This paper has shown that the evolution of financial market participation induces an apparent instability in aggregate money demand. Persistent changes in interest rate, wealth or cost of holding non-monetary assets, affect persistently the level of aggregate money holdings and the sensitivity of money demand to interest rate fluctuations. Moreover, at the time these changes occur, aggregate money demand relationships are seriously affected. As a result, elasticity estimates obtained from time series analysis do not reflect the actual response of money holdings to scale variables and opportunity costs.

The analysis of this paper has shown the need for cross-sectional analysis to uncover the true structural parameters of money demand relationships. A full understanding of the behavior of monetary aggregates would require modelling simultaneously the money demand of households, firms, and the foreign sector. Moreover, gaining further knowledge on the nature of participation costs and their evolution would be essential to predict changes in aggregate money demand. Other research areas can be further explored using the approach and data sets presented in this paper. A measure of financial market participation incorporating assets upon which households have a direct short-term control can be useful in financial studies and in monetary policy analysis. Most importantly, results in this paper indicate that financial market developments can seriously affect macroeconomic relationships, like for example the link between money and output. Further work should be directed towards understanding those effects. 


\section{APPENDIX: DATA SOURCES}

The series for nominal GDP, GDP price deflator, consumer prices, federal funds rate, 3-month Treasury bill rate, as well as for the monetary aggregates and their components, were obtained from the Federal Reserve Bank of St. Louis FRED database, and are released by the Federal Reserve Board, the Bureau of Economic Analysis and the Bureau of Labor Statistics. Monetary series prior to 1959 are from Rasche (1987, 1990). Interest rates paid on the various monetary assets were obtained from Ruth Judson and Robert Rasche. The commercial paper rate is from the Federal Reserve Board H15 series and from the Economic Report of the President, table B-73. All series except interest rates are seasonally adjusted.

Surveys of Consumer Finances (SCF) were conducted by the Survey Research Center of the University of Michigan, from 1947 until 1989, and by the National Opinion Research Center at the University of Chicago since 1992. SCF data have been collected annually, from 1947 to 1971, and in 1977. Then, from 1983 on, these surveys have been conducted on a triennial basis. Survey data for the years 1962, 1983, 1989, 1992, 1995, and 1998, were obtained from the Federal Reserve Board, and the additional surveys were obtained from the Inter-University Consortium for Political and Social Research (ICPSR) through the Data Library at the University of Chicago. The acknowledgment of assistance requested by the ICPSR is displayed in the next paragraph.

The data were made available by the ICPSR. The data for these SCF were originally collected by the Economic Behavior Program, Institute for Social Research, The University of Michigan, under grants from several foundations, especially the Ford Foundation and the National Science Foundation, and from various industrial 
organizations with Ford Motor Company and General Motors contributing the major portion of the funding. Neither the original collectors of the data nor the Consortium bear any responsibility for the analyses or interpretations presented in this paper. 


\section{REFERENCES}

Anderson, R.G., 1997a. Federal Reserve Board Data on OCD Sweep Account Programs, The Federal Reserve Bank of St. Louis internet site.

Anderson, R.G., 1997b. Sweeps Distort M1 Growth, The Federal Reserve Bank of St. Louis internet site.

Attanasio, O.P., Guiso, L., Jappelli, T., 2002. The Demand for Money, Financial Innovation, and the Welfare Cost of Inflation: an Analysis with Households' Data, Journal of Political Economy 110 (2), 317-351.

Avery, R.B., Elliehausen, G.E., 1985. 1983 Survey of Consumer Finances: Technical Manual and Codebook, Board of Governors of the Federal Reserve System internet site.

Avery, R.B., Canner, G.B., Elliehausen, G.E., Gustafson, T.A., 1984. Survey of Consumer Finances, 1983, Federal Reserve Bulletin 70, September, 679-692.

Blume, M.E., Irwin, F., 1975. The Asset Structure of Individual Portfolios and Some Implications for Utility Functions, Journal of Finance 30 (2), 585-603.

Carlson, J.B., Keen, B.D., 1996. MZM: A Monetary Aggregate for the 1990s?, Federal Bank of Cleveland Economic Review, Second Quarter, 15-23.

Collins, S., Edwards, C.L., 1994. An Alternative Monetary Aggregate: M2 Plus Household Holdings of Bond and Equity Mutual Funds, Federal Reserve Bank of St. Louis Review 76 (6), 7-24.

Dotsey, M., 1985. The Use of Electronic Funds Transfers to Capture the Effects of Cash Management Practices on the Demand for Demand Deposits: A Note, The Journal of Finance 40 (5), 1493-1503.

Economic Behavior Program Staff, Survey of Consumer Finances, annual volumes 
and codebooks, 1960 through 1970, 1971 and 1977 (Survey Research Center, University of Michigan; Institute for Social Research, and Inter-University Consortium for Political and Social Research, Ann Arbor, Michigan).

Farr, H.T., Porter, R.D., Pruitt, E.M., 1978. Demand Deposit Ownership Survey, in: Improving Monetary Aggregates, Staff Papers (Board of Governors of the Federal Reserve System, Washington D.C.) 91-116.

Guide to the Flow of Funds Accounts, 2000 (Board of Governors of the Federal Reserve System, Washington D.C.).

Judd, J.P., Motley, B., 1984. The "Great Decline" of 1982-83: A Comparative Analysis of M1 and M2, Federal Reserve Bank of San Francisco Economic Review (3), 56-74.

Judd, J.P., Scadding, J.L., 1982. The Search for a Stable Money Demand Function: A Survey of the Post-1973 Literature, Journal of Economic Literature 20, 993-1023.

Kennickell, A.B., Starr-McCluer, M., 1994. Changes in Family Finances from 1989 to 1992: Evidence from the Survey of Consumer Finances, Federal Reserve Bulletin 80, October, 861-82.

Kennickell, A.B., Starr-McCluer, M., Surette, B.J., 2000. Recent Changes in U.S. Family Finances: Results from the 1998 Survey of Consumer Finances, Federal Reserve Bulletin 86, January, 1-29.

Mandell, L., Katona, G., Morgan, J., Schmiedeskamp, J., 1973. Surveys of Consumers, 1971-1972: Contributions to Behavioral Economics (Ann Arbor, Michigan: Institute for Social Research).

Mankiw, N.G., Zeldes, S.P., 1991. The Consumption of Stockholders and Nonstockholders, Journal of Financial Economics 29, 97-112. 
Mishkin, F.S., 1986. The Economics of Money, Banking, and Financial Markets (Little, Brown and Company (Canada) Limited).

Moore, G.R., Porter, R.D., Small, D.H., 1990. Modeling the Disaggregated Demands for M2 and M1: The U.S. Experience in the 1980s, in: Hooper, P. et al., eds., Financial Sectors in Open Economies: Empirical Analysis and Policy Issues (Board of Governors of the Federal Reserve System, Washington D.C.) 21-105.

Motley, B., 1988. Should M2 Be Redefined?, Federal Reserve Bank of San Francisco Economic Review, Winter, 33-51.

Mulligan, C.B., Sala-i-Martin, X., 2000. Extensive Margins and the Demand for Money at Low Interest Rates, Journal of Political Economy 108 (5), 961-991.

Poole, W., 1991. Statement before the Subcommittee on Domestic Monetary Policy of the Committee on Banking, Finance, and Urban Affairs, U.S. House of Representatives, November 6 .

Porter, R.D., Simpson, T.D., Mauskopf, E., 1979. Financial Innovation and the Monetary Aggregates, Brookings Papers on Economic Activity (1), 213-229.

Projector, D.S., 1964. Survey of Financial Characteristics of Consumers, Federal Reserve Bulletin 51, March, 285-293.

Projector, D.S., Weiss, G.S., 1966. Survey of Financial Characteristics of Consumers, Federal Reserve Technical Papers (Washington D.C).

Rasche, R.H., 1987. M1 - Velocity and Money Demand Functions: Do Stable Relationships Exists?, Carnegie-Rochester Conference Series on Public Policy 27, 988.

Rasche, R.H., 1990. Demand Functions for Measures of U.S. Money and Debt, in: Hooper P. et al., eds, Financial Sectors in Open Economies: Empirical Analysis and 
Policy Issues (Board of Governors of the Federal Reserve System, Washington D.C.) 159.

Rotemberg, J.J., Driscoll, J.C., Poterba, J.M., 1995. Money, Output, and Prices: Evidence from a New Monetary Aggregate, Journal of Business \& Economic Statistic $13(1), 67-83$.

Stock, J.H., Watson, M.W., 1993. A Simple Estimator of Cointegrating Vectors in Higher Order Integrated Systems, Econometrica 61 (4), 783-820.

Uhler, R.S., Cragg, J.G., 1971. The Structure of the Asset Portfolios of Households, Review of Economic Studies 38, 341-357.

Vissing-Jørgensen, A., 2002. Towards an Explanation of Household Portfolio Choice Heterogeneity: Nonfinancial Income and Participation Cost Structures, manuscript, The University of Chicago. 
Swiss National Bank Working Papers published since 2004:

2004-1 Samuel Reynard: Financial Market Participation and the Apparent Instability of Money Demand. 
Swiss National Bank Working Papers are also available at www.snb.ch, section Publications/Research Hard copies can be ordered by phoning +41 163132 84, mailing library@snb.ch or faxing +41 16318114 To subscribe to the Swiss National Bank Working Papers series, please send an e-mail to adressverwaltung@snb.ch or a fax to +41 16313171 